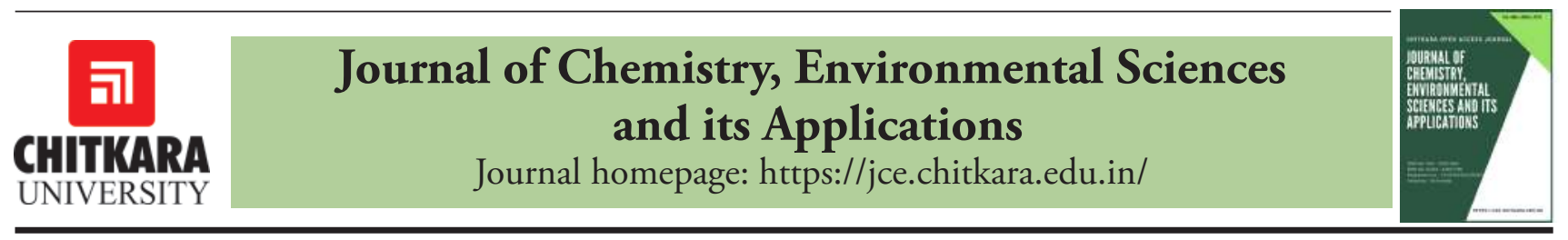

\title{
Eco-management of Wastewater by ZESTP
}

\author{
Uday Bhan Prajapati ${ }^{1}$, Arun Lal Srivastav ${ }^{2 *}$ and Shiraz A.Wajih ${ }^{3}$ \\ ${ }^{1}$ Scientist, Patanjali Research Institute, Haridwar, 249405, Uttarakhand, India \\ ${ }^{2}$ Assistant Professor, Chitkara University School of Engineering and Technology, Chitkara University, 174103, Himachal Pradesh, India \\ ${ }^{3}$ President, Gorakhpur Environmental Action Group (GEAG), Gorakhpur, 273017, Uttar Pradesh, India \\ 2Email: arun.srivastav@chitkarauniversity.edu.in | arunitbhu2009@gmail.com
}

\section{ARTICLE INFORMATION}

Received: 12 Jan 2018

Revised: 17 Feb 2018

Accepted: 21 Feb 2018

Published online: 06 March 2018

Keywords:

ZESTP, Ecomanagement, Wastewater, Phytoremediation.

DOI: https://doi.org/10.15415/jce.2018.42007

\begin{abstract}
In present study, an evaluation of ZESTP (Zero Energy Sewage Treatment Plant) has been described as an alternative solution of sewage water treatment. This system has become widely famous because of having great absorption efficiency of nutrients, simple construction and maintenance, relatively less costly as well as a strong process. After treatment of sewage water, the level of dissolve oxygen was increased up to $73 \%$ due to the enhanced numbers of photosynthetic organisms. Some aquatic macrophytes such as Eichhornia crassipes (Mart.) Solms, Pistia stratiotes L. and Hydrilla verticillata Casp were used in ZESTP for waste water treatment based on phytoremediation. ZESTP could reduce the around $84 \%$ turbidity, $46 \%$ electrical conductivity, $43 \%$ salinity, $74 \%$ acidity, $69 \%$ free CO2, $73 \%$ BOD, $44 \%$ COD, $70 \%$ suspended solids, $62 \%$ total hardness, $71 \%$ chloride, $59 \%$ cadmium, $51 \%$ iron, and $71 \%$ copper from the waste water. Naturally, some plants have capability are to retain and/or remove fatal chemicals which are present in sewage water. Moreover, macrophytes based ZESTP is a cost effective and an eco-friendly technique of sewage water treatment.
\end{abstract}

\section{Introduction}

Generally, sewage, a waste material which is mostly derived from municipalities, animal shelters, food industries, excreta of human beings, paper, soaps and detergents. It poses several human health problems and still it is needed to develop effective and affordable technological solutions for management. Gorakhpur is a district headquarters of state Uttar Pradesh (located at the Terai belt) of India lies between $26^{\circ} 75^{\prime} \mathrm{N}$ and $83^{\circ} 36^{\prime} \mathrm{E}$. The city is situated in the plain of Saryu at mid Gangetic valley and the confluence of rivers Rapti and Rohini [7] Cached-Similar. The major water source of Gorakhpur city is ground water. The major water source of Gorakhpur city is ground water in which 75 powers bore well, 8 mini power well, 3694 hand pumps and 450 public stand posts are involved for groundwater extraction. Approximately, 82 MLD (Million liters per day) water produced from only ground water and not a single unit of water is produced from surface water sources. On an average, the supply of domestic water is 77.60 LPCD (Liter per capita per day) and nearly $70 \%$ of this amount of domestic water is being released in Gorakhpur city as wastewater which is around 65.84 MLD. It poses several human health problems; therefore a need has arisen to develop effective and affordable technological solutions.
The ZESTP technology was developed to purify the water on site naturally. Moreover, it has ability to eliminate various types of fatal chemicals or contaminants from sewage water. Additionally, ZESTP technique has several advantages over the traditional wastewater purification systems because of relatively less cost of operation and maintenance, need of least energy as well as in-situ water treatment facility.

\section{Material and Methods}

Sewage samples were analyzed for all the water quality parameters as per the recommendations of APHA [2]. Physical water parameters like colour and odour were analyzed manually on the sampling collection sites. On the other hand, analyses of the other water parameters were carried out into the laboratory. On the basis of nature of contaminants, their resistance capacities as well as sensitivity, three aquatic macrophytes such as Eichhornia crassipes (Mart.) Solms, Pistia stratiotes L. and Hydrilla verticillata Casp were chosen for the study. The experiment was conducted for biological treatment and analyzed for a period of 20 days at the interval of 5 days during the treatment process. For mixed culture experiments, five aquaria of $25 \mathrm{~L}$ capacity were maintained. 
Initial reading of all the variables was also recorded for the comparison of results. In each aquarium $25 \mathrm{~L}$ waste water was poured and roots of all selected macrophytes were washed thoroughly in tap water before the placing plants in aquarium. Best results were obtained in case of $15^{\text {th }}$ day of treatment, therefore, only the reading of 15 days is expressed here. In the light of above experiment ZESTP model (Figure 1b) was developed which have shown 2270 liter purifying capacity in peri-urban part of Gorakhpur city (Jangal bahadur Ali block Chargawa). Zero Energy Sewage Treatment Plant (ZESTP) is a three chambered Sewage Treatment Plant made up of brick, cement, plastic pipe, barrel pump and iron net which works without using energy. It is able to treat sewage water using aquatic plants.

ZESTP works in following three steps (figure 1a):

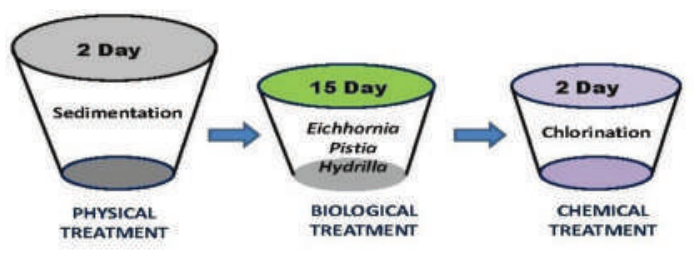

a.
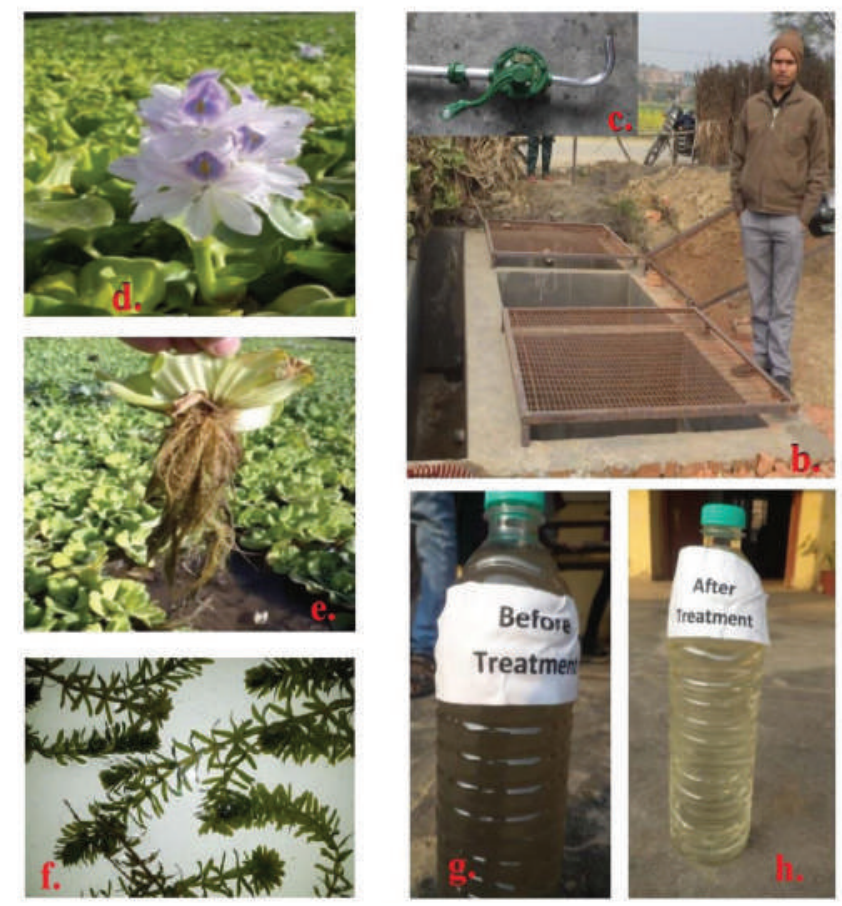

Figure 1a: Flow diagram of ZESTP. b: Zere Energy Sewage Treatment Plant (ZESTP), c: Barrel Pump, d: Eichhornia crassipes (Mart.) Solms., e: Pistia stratiotes L., f: Hydrilla verticillata Casp., g: Sewage sample before Treatment, h: Sewage sample after Treatment.
Step I: Collection of sewage directly in the first tank and stay for two days.

Step II: Transfer the stagnant sewage water (except precipitate) from 1st chamber to second tank of ZESTP with the help of barrel pump (figure 1c), then implant aquatic macrophytes (Two plants of each Eichhornia, Pistia and Hydrilla per square feet) for 15 days.

Step III: After 15 days, transfer the second tank water into third tank with the help of barrel pump followed by chlorination $(5 \mathrm{gm} / 100 \mathrm{~L})$ and leave water for two days before irrigation or other application of treated sewage.

In general, Eichhornia crassipes (Mart.) Solms is known as water hyacinth (Figure 1d) belongs to family Pontederiaceae. It is a perennial, free floating; consisting of horizontal and spongy stem having large aerial leaves, cluster of brown or pinkish adventitious root with root pockets, growing by the means of offset. Eichhornia crassipes is monocotyledonous and cosmopolitan in distribution.

Pistia stratiotes L. commonly known as water lettuce (Figure 1e) belong to monocotyledonous of family Araceae. Plants are small, free floating, perennial aquatic herbs of gregarious nature with sessile and spatiualate leaves. They arise in close spirals and form cup shaped rosette in the region of nodes. Roots bear root pocket.

Hydrilla verticillata Casp is a submerged plant belonging to family Hydrocharitaceae of monocot. It is free floating and herbaceous in nature. Hydrilla verticillata (Figure 1f) release high amount of oxygen directly into the water.

\section{Treatment Capacity}

One cubic foot $(1 \times 1 \times 1)$ area have $\quad=28.317 \mathrm{~L}$ water $=28 \mathrm{~L}$ and $317 \mathrm{~mL}$

Total area covered by ZESTP - $\quad=15 \times 4$ feet

$$
=60 \text { square feet }
$$

Total requirement of aquatic macrophytes:

(Eichhornia, Pistia and Hydrilla)

$$
\begin{aligned}
& =60 \times 2 \text { macrophytes each } \\
& =\quad 120 \quad \text { macrophytes }
\end{aligned}
$$

\section{Size of one tank:}

$$
\begin{aligned}
& =4 \text { Length } \times 5 \text { Breadth } \times 4 \text { Depth } \\
& =80 \text { cubic foot } \\
& =80 \times 28.371 \\
& =2269.68 \mathrm{~L} \text { water }
\end{aligned}
$$

Therefore, after complete operation of ZESTP can purify nearly $2270 \mathrm{~L}$ sewage water in every 15 days. 
Table 1: Result of Biological Treatment (initial and after 15 days), ${ }^{*}$ Increase Percentage ${ }^{*}$ *Standard by CPCB [6].

\begin{tabular}{|c|c|c|c|c|c|}
\hline $\begin{array}{l}\text { S. } \\
\text { No. }\end{array}$ & & $\begin{array}{l}\text { Before } \\
\text { Treatment }\end{array}$ & $\begin{array}{l}\text { After } \\
\text { Treatment (Mix } \\
\text { Culture) }\end{array}$ & Reduction (\%) & Standard ${ }^{* *}$ \\
\hline & Parameter & $\mathrm{mg} / \mathrm{L}$ & $\mathrm{mg} / \mathrm{L}$ & - & $\mathrm{mg} / \mathrm{L}$ \\
\hline 1 & Colour & Blackish & Light yellowish & - & -- \\
\hline 2 & Odour & Sewer like & Light smell & - & -- \\
\hline 3 & Temperature & $38.5^{\circ} \mathrm{C}$ & $28.8^{\circ} \mathrm{C}$ & - & -- \\
\hline 4 & $\mathrm{pH}$ & 7.86 & 7.12 & - & $5.5-9.0$ \\
\hline 5 & Turbidity & 76 & 12 & 84.21 & -- \\
\hline 6 & Electrical conductivity & 512 & 278 & 45.70 & -- \\
\hline 7 & Salinity & 234 & 134 & 42.73 & - \\
\hline 8 & Total solid (TS) & 1270 & 817 & 35.66 & 600 \\
\hline 9 & Total Dissolve solid (TDS) & 815 & 678 & 16.80 & 600 \\
\hline 10 & Total Suspended solid (TSS) & 455 & 139 & 69.45 & $<100$ \\
\hline 11 & Acidity & 145 & 37.8 & 73.93 & - \\
\hline 12 & Alkalinity & NIL & NIL & NIL & - \\
\hline 13 & Free $\mathrm{CO}_{2}$ & 145 & 44.5 & 69.31 & - \\
\hline 14 & Total Hardness & 660 & 248 & 62.42 & - \\
\hline 15 & Chloride & 130.4 & 38.2 & 70.70 & - \\
\hline 16 & $\mathrm{DO}^{*}$ & 2.4 & 8.8 & $72.72^{*}$ & $4-6$ \\
\hline 17 & BOD & 185 & 50 & 72.97 & $<100$ \\
\hline 18 & $\mathrm{COD}$ & 210 & 118 & 43.80 & $<150$ \\
\hline 19 & Cadmium & 0.457 & 0.187 & 59.08 & -- \\
\hline 20 & Iron & 2.00 & 0.985 & 50.75 & -- \\
\hline 21 & Copper & 0.905 & 0.211 & 76.69 & -- \\
\hline
\end{tabular}

\section{Results and Discussion}

\section{3a. Colour, Odour and Temperature}

The colour of sewage water was light black (figure $1 \mathrm{~g}$ ) due to the decomposition of organic pollutants, formation of humic acid which gives dirty colour after getting dissolved as similar observations were also reported by Singh et al. [17]. Temperature fluctuation was observed during the change of environmental conditions. Stink was observed form the water due to decomposition of organic matter over the study site [1]. The colour of sewage water was changed to light yellowish (figure $1 \mathrm{~h}$ ) from dark blackish by biological treatment. Moreover, after treatment odour and temperature were reduced favorably (Table 1).

\section{3b. pH}

$\mathrm{pH}$ is an important parameter which indicates the water quality and treatment efficiency. $\mathrm{pH}$ of water always fluctuates due to microbial degradation as well as different aquatic chemical reactions. It was found that the selected vegetation of water hyacinth significantly reduced the $\mathrm{pH}$ of wastewater. $\mathrm{pH}$ of treated effluent was found near to 
neutral, though it was decreased in small percentage than inlet. Such reduction in $\mathrm{pH}$ with the help of water hyacinth was also reported by Wolverton and McDonald [18]. Initial $\mathrm{pH}$ was is 7.86 before treatment and it got reduced up to 7.12 by using macrophyte Eichhornia, Pistia, Hydrilla in mixed culture experiment, respectively. The mixed culture of macrophytes was able to reduce $\mathrm{pH}$ which gives only the intensity of acidic or basic character and not the total acidity or alkalinity.

\section{3c. Turbidity and Conductivity}

During the month of June, both temperature as well as Brownian movement was observed elevated. Moreover, total suspended solids concentration in water was also enhanced which suggests about its involvement in increasing the level of turbidity because colloidal suspended particles could not settle down easily and found responsible for turbid appearance. Capacity of passing electric current through any liquid can be determined by estimating the conductivity of solution. For example, inorganic and organic materials shows better and poor conductance, respectively. The initial readings of turbidity and conductivity were recorded as $76 \mathrm{mg} / \mathrm{l}$ and $512 \mathrm{mS} / \mathrm{cm}$, respectively. Heavy reductions in Turbidity and Conductivity were observed as $84.21 \%$ and $45.70 \%$, respectively by the use of aquatic macrophytes during the treatment (Table 1).

\section{3d. TS, TDS and TSS}

The residue left after evaporation of unfiltered weight of water is known as total solids (TS), whereas residue left after evaporation of the filtrate water sample is known as total dissolved solid (TDS. Increase in the level of turbidity and decrease in the light penetration capacity may due to the presence of suspended solids. Moreover, this can contribute in the enhanced level of pollution as well by adding pollutants from their sediments. Reduction in suspended solids is helpful to decrease the turbidity as well as BOD load of water. Through stems, the Eichhornia crassipes (Mart.) Solms indicates about the presence aerobic conditions in their root systems which may favors the growth of aerobic bacterial colonies. Karthikeyan and Singh [9] studied that high concentrations of total solids and total dissolved solids cause problems to the soil health because of least aeration and also favors high BOD levels. Additionally, it will affects the occurrence of trace elements. Mixed culture of aquatic macrophytes has reduced the concentration of TS $(35.66 \%)$, TDS (16.80\%) and TSS (69.45\%) in sewage water, as given in Table 1 and Fig. 1. Because, the Eichhornia provides suitable environment of microbial growth, also retards the flow of water by capturing suspended solids.

\section{3e. Free $\mathrm{CO}_{2}$ and Chloride}

Accumulation of free Carbon dioxide in water takes place due to microbial activity and respiration of organism; this imparts acidity to the water by the formation of carbonic acid. Free $\mathrm{CO}_{2}$ and chloride were decreased up to $44.5 \mathrm{mg} / \mathrm{l}$ $(69.31 \%)$ and $38.2 \mathrm{mg} / \mathrm{l}(70.70 \%)$ from $145 \mathrm{mg} / \mathrm{l}$ and $130.4 \mathrm{mg} / \mathrm{l}$, respectively as also shown in Table 1 .

\section{3f. Acidity, Alkalinity and Hardness}

Acidity is the capacity of water which can neutralize a strong base. It is an aggregate property of water due to several specific substances but chiefly it is due to the $\mathrm{CO}_{2}$ dissociating from carbonic acid. Alkalinity is a quantitative capacity of neutralizing strong acid to a designated $\mathrm{pH}$. Table 1 shows reducing potential of mixed culture of plants, in respect of acidity $(73.93 \%)$ and hardness (62.42\%). Acidity which is 145 $\mathrm{mg} / \mathrm{l}$ before treatment reduced to $44.5 \mathrm{mg} / \mathrm{l}$ after treatment in the mixed culture of Eichhornia, Pistia and Hydrilla. Hardness of water is generally the results of dissolution of the salts of calcium and magnesium compounds present in water.

\section{3g. Dissolve Oxygen (DO)}

The amount of oxygen dissolved in water is known as DO. The main sources of DO in water are photosynthesis and/ or atmospheric diffusion. It is an important water quality parameter. Low concentration of DO indicates higher pollution load in the wastewater which affect the treatment efficiency. In the constructed wetlands, all the inlet samples collected were devoid of DO. Macrophytes play a very important role in increasing DO levels through the process of photosynthesis. Such increased DO levels favors the aerobic microflora in the wastewater involved in degradation activity [4]. The increased DO helps to reduce BOD load of wastewater. It was also indicated by reduction of $\mathrm{BOD}$ and $\mathrm{COD}$ in the wastewater and also increases the mass weight of the vegetation. DO have a significant role in the treatment of wastewater as it can directly affect the removal of various types of pollutants [8]. For the treatment of wastewater, a constructed wetland system was developed which had improved levels of DO due to the application of Eichhornia crassipes [19]. A tremendous increase in dissolve oxygen by mixed culture was recorded. Initially, DO was $2.4 \mathrm{mg} / \mathrm{l}$, which increased to $8.8 \mathrm{mg} / \mathrm{l}$ through aquaculture of mixed culture respectively. An increase of $-73 \%$ dissolved oxygen concentration was observed level increased due to photosynthetic activity (Table 1).

\section{3h. Biological Oxygen Demand (BOD) and Chemical Oxygen Demand (COD)}

Oxygen requirement of microorganism for the decomposition of biodegradable materisl present in water is 
known as BOD. Biochemical Oxygen Demand (BOD) was used to check the organic load in the water body. Biological oxygen demand can be used to indicate the amount of organic matter in the water. High BOD levels reflects that more oxygen will be consumed as organic matter decays leading to low dissolved oxygen levels. Similar reduction in BOD has been reported by using bio filter for treatment of wastewater [14]. The reduction in BOD occurred due to aerobic, anoxic and anaerobic microbial processes in the constructed wetland system. Water hyacinths have the ability of removing pollutants from water by absorbing their tissues for providing a suitable growth environment to the microorganisms for pollutants transformation as well as their removals [18]. Whereas, the oxygen concentration required tooxidize the biodegradable as well non-biodegradable materials present in water using strong oxidizing agent is known as COD. The initial reading of $\mathrm{COD}$ and $\mathrm{BOD}$ was recorded to be 210 and $185 \mathrm{mg} / \mathrm{L}$ respectively (Figure 2), which show tremendous reduction by the use of aquatic macrophytes recorded after treatment. Choudhary [5] showed $87.17 \%$ reduction in COD with Eichhornia crassipes (Mart.) Solms. Such reduction is helpful in increasing the DO level in the wastewater. Roy et al. [15] also worked on the various types of aquatic macrophytes as well as algae (Nostoc, E. crassipes and P. stratiotes) and observed very effective to reduce the level of COD $(-69 \%)$ in water. In present study, the level of COD was reduced as $72.97 \%$ in $\mathrm{BOD}$ and $43.80 \%$ in $\mathrm{COD}$ as well.

\section{3i. Heavy metals}

The concentration of toxic heavy metals such as $\mathrm{Cd}$ $(0.457 \mathrm{ppm}), \mathrm{Fe}(2.00 \mathrm{ppm})$ and $\mathrm{Cu}(0.905 \mathrm{ppm})$ were observed significantly higher in sewage water while $\mathrm{Pb}$ and $\mathrm{Cr}$ were found nil. These heavy metals concentrations were reduced $59.08 \%$ for $\mathrm{Cd}, 50.75 \%$ for $\mathrm{Fe}$ and $76.68 \%$ for $\mathrm{Cu}$ ) after biological treatment (Table 1). Enhance level of heavy metal in the aquatic environment causes several health problems in living creatures. Mohanty et al. [13] were carried out an experiment on aquatic submerged plant i.e. E. crassipes which was found very well in the removal of chromium from water. Around $73 \%$ to $89 \%$ removal of $10 \mathrm{mg} / \mathrm{L}$ initial concentration was observed with 0.05 to $0.2 \mathrm{~g} / 100 \mathrm{~mL}$ biosorbent dosage range indicating that the biomass of $E$. crassipes is efficient biosorbent for the removal of chromium from waste water. Combined application of $E$. crassipes and $L$. minor was found better in the removal of heavy metals form water [12] and this can be applicable for the treatment of waste water at large scale. Mishra and Tripathi [11] used E. crassipes for the accumulation of $\mathrm{Cr}$ and $\mathrm{Zn}$ from water up to 3.542 and $2.412 \mathrm{mg} / \mathrm{g}$ at $10 \mathrm{mg} / \mathrm{L}$ initial metal concentration with an exposure of 11 days.
Using ZESTP, $84 \%$ of $\mathrm{Cr}$ and $94 \%$ of $\mathrm{Zn}$ were removed successfully (Table 2 ).

Table 2: Removal efficiency of aquatic macrophytes.

\begin{tabular}{|c|c|c|}
\hline $\begin{array}{l}\text { Aquatic } \\
\text { Macrophyte }\end{array}$ & $\begin{array}{l}\text { Heavy Metal Removal } \\
\text { Capacity }(\%)\end{array}$ & References \\
\hline \multirow[b]{2}{*}{ Pistia stratoites } & $\begin{array}{l}\mathrm{Fe}(95 \%), \mathrm{Cu}(96 \%), \mathrm{Cd} \\
(82 \%), \mathrm{Cr}(81 \%), \mathrm{Zn} \\
(92 \%)\end{array}$ & $\begin{array}{l}\text { Mishra and } \\
\text { Tripathi [11] }\end{array}$ \\
\hline & $\begin{array}{l}\mathrm{Cd}(83.24 \%), \\
\mathrm{Ni}(32.77 \%), \mathrm{Cu} \\
(94.48 \%), \mathrm{Zn}(26.08 \%) \\
\mathrm{Pb}(54.77 \%)\end{array}$ & $\begin{array}{l}\text { Miretzky et al. } \\
{[10]}\end{array}$ \\
\hline \multirow{4}{*}{$\begin{array}{l}\text { Eichhornia } \\
\text { crassipes }\end{array}$} & Cr (VI) $(73-89 \%)$ & $\begin{array}{l}\text { Mohanty et al. } \\
\text { [13] }\end{array}$ \\
\hline & $\begin{array}{l}\mathrm{Fe}(90.1 \%), \mathrm{Cu}(95 \%) \\
\mathrm{Cd}(85 \%), \mathrm{Cr}(84 \%), \mathrm{Zn} \\
(95 \%)\end{array}$ & $\begin{array}{l}\text { Mishra and } \\
\text { Tripathi }[11]\end{array}$ \\
\hline & $\mathrm{Fe}(89 \%)$ & $\begin{array}{l}\text { Singh and Rai } \\
{[16]}\end{array}$ \\
\hline & $\begin{array}{l}\mathrm{Fe}(92.39 \%), \mathrm{Cu} \\
(90.12 \%), \mathrm{As}(65.30 \%)\end{array}$ & Banerjee, et al. [3] \\
\hline Mixed Culture & $\begin{array}{l}\mathrm{Cu}(76.69 \%), \mathrm{Cd} \\
(59.08 \%), \mathrm{Fe}(50.75 \%)\end{array}$ & $\begin{array}{l}\text { ZESTP (Present } \\
\text { study) }\end{array}$ \\
\hline
\end{tabular}

Miretzky et al. [10] simultaneously removed $\mathrm{Cd}, \mathrm{Ni}, \mathrm{Cu}$, $\mathrm{Zn}$, and $\mathrm{Pb}$ form water using $S$. intermedia, L. minor and $P$. stratiotes. The species L. minor biomass was found best as it could remove $84.52 \%$, whereas $P$. stratiotes was found least performer in the same work. Interestingly, $\mathrm{Pb}$ and $\mathrm{Cd}$ were efficiently removed by all the above macrophytes. Heavy metals such as $\mathrm{Pb}$ and $\mathrm{Cd}$ removals using $S$. intermedia, L.minor and $P$. stratiotes were observed a potential and less costly method of industrial waste water treatment.

\section{Conclusion}

The colour of waste water was changed light yellowish from dark blackish by biological treatment. After treatment, odour became light smell and temperature reduced as well. $\mathrm{pH}$ which was 7.86 before treatment but reduced up to $7.12(9.41 \%)$ by using these macrophytes. Mixed culture of aquatic plant reduces the concentration of TS (35.66), TDS $(16.80 \%)$ and TSS $(69.45 \%)$ in waste water. Free $\mathrm{CO}_{2}$ and chloride were $145 \mathrm{mg} / \mathrm{l}$ and $130.4 \mathrm{mg} / \mathrm{l}$ respectively before treatment and those were reduced after treatment $44.5 \mathrm{mg} / \mathrm{l}(69.31 \%)$ and $38.2 \mathrm{mg} / \mathrm{l}(70.70 \%)$ by mixed culture. Initially, DO was $2.4 \mathrm{mg} / \mathrm{l}$ which was increased up to $8.8 \mathrm{mg} / \mathrm{I}(72.42 \%)$ through mixed culture. COD and BOD were $210 \mathrm{mg} / \mathrm{l}$ and $185 \mathrm{mg} / \mathrm{l}$ before treatments which had shown tremendous reductions as $43.80 \% \mathrm{COD}$ and 
72.97\% BOD after treatment. Aquatic macrophytes have shown rapid growth rate, absorb large quantity of nutrients which would provide practical and economical method for tertiary treatment. As an outcome of the complete remedial experiments, mixed culture of the selected aquatic macrophytes for 15 days is suggested for the best performance. The concentration of toxic metals such as $\mathrm{Cd}(0.457 \mathrm{mg} / \mathrm{l}), \mathrm{Fe}(2.00 \mathrm{mg} / \mathrm{l})$ and $\mathrm{Cu}(0.905 \mathrm{mg} / \mathrm{l})$ were significantly higher in sewage water while $\mathrm{Pb}$ and $\mathrm{Cr}$ were nil. These heavy metals concentrations were reduced $(\mathrm{Cd}-$ $59.08 \%, \mathrm{Fe}-50.75 \%$ and $\mathrm{Cu}-76.68 \%$ ) after biological treatment. ZESTP is an on-site and established technique of wastewater treatment systems which depends on the application of macrophytes. Additionally, it is less costly, requires less energy with respect to traditional waste water purification units. Also, it could be an attractive and cost effective option over the existing technologies for the removal of metal ions. Phytoremediation is being significantly used for the removal of contaminated wastewater using natural ability of macrophytes to remove toxic chemicals/pollutants from wastewater. Therefore, ZESTP can be introduced for the removal of contaminants using these above studied macrophytes because of its eco-friendly nature.

\section{4a. Precautions to be taken for the management of ZESTP}

- Need of well cleaning of ZESTP at regular intervals.

- Removal of old plants after 15 days and implant new one.

- Wash the aquatic plant with tap water before implantation.

- Always cover iron net above the tank.

- Use barrel pump for the transfer of water from one tank to another.

\section{4b. Advantages of ZESTP treated sewage water}

- In irrigation of agricultural crops and vegetables.

- For aquaculture of fish.

- Save energy.

- Reduce the exploitation of ground water.

- Optimum utilization of municipal sewage water.

\section{Acknowledgement}

The authors are grateful to Department of Botany, M.G.P.G. College, Gorakhpur and Prof. Prabhat Kumar Singh, Department of Civil Engineering, I.I.T. (B.H.U.) Varanasi for providing facilities to analyze heavy metals in the water samples.

\section{References}

[1] Ahmad, S., Choudhary, S, Akhtar A. (2006). Effect of sewage pollution on physicochemical characteristics of Ganga water near Patna. Modern J. Life Sci, 5(1-2), 23-26.

[2] APHA. (1998). Standard methods for the examination of water and waste water, 20thEd. American Public Health Association, Washington DC-USA.

[3] Banerjee, S., Mukherjee, S., LaminKa-ot, A., Joshi, S. R. Mandal, T., Haldera, G. (2016) Biosorptive uptake of $\mathrm{Fe}^{2+}, \mathrm{Cu}^{2+}$ and $\mathrm{As}^{5+}$ by activated biochar derived from Colocasia esculenta: Isotherm, kinetics, thermodynamics, and cost estimation. J Adv Res. 7(5), 597-610. doi: 10.1016/j.jare.2016.06.002

[4] Bastviken, S. (2006). Nitrogen removal in treatment wetlands- Factors influencing spatial and temporal variations, Linkoping Studies in Science and Technology, Linkoping University, Sweden.

[5] Choudhary, M. (2007). Water Hyacinth -A complete solution to wastewater treatment, Reclamation and Environment Protection IE (I) Journal-EN, 52-54.

[6] CPCP. (2018). Industry effluent standards. http:// cpcb.nic.in/industry-effluent-standards/ Accessed 28 May 2018

[7] Gorakhpur. (2018). http://en.wikipedia.org/wiki/ Gorakhpur. Accessed 28 May 2018

[8] Hiley, P. D. (1995). The reality of sewage treatment using wetlands. Water Science and Technology 32(3), 68-83.

[9] Karthikeyan, K., Singh, K. (2004). Chemical composition of some sewage water used for irrigation purpose. Jr. of industrial pollution control, 20(2), 211-219.

[10] Miretzky, P., Saralegui, A., Cirelli, A. F. (2006). Simultaneous heavy metal removal mechanism by dead macrophytes. Chemosphere, (62), 247-254.

[11] Mishra, V. K., Tripathi, B. D. (2009). Accumulation of chromium and zinc aqueous solution using water hyacinth (Eichhornia crassipes). Journal of Hazardous material, (164), 1059-1063.

[12] Mishra., V. K., Upadhyay, A. K., Pandey, S. K., Tripathi, B. D. (2008). Heavy metal pollution induced due to coal mining effluent on surrounding aquatic ecosystem and its management through naturally occurring aquatic macrophyte Bioresource Technology, (99), 930-936.

[13] Mohanty, K., Jha, M., Meikap, B. C., Biswas, M. N. (2006). Biosorption of $\mathrm{Cr}$ (IV) from aqueous solution by Eichhornia crassipes. Chemical Engineering Journal, (117), 71-77. 
[14] Nadirah, I., Zaharah, I., Zaiton, A. M., Siti Haryani, C. K., Fadhil, M. (2008). Application of Bioparticle in Biofilter PI 20062119 for Wastewater Treatment. International Conference and Expo on Environmental Management and Technologies (ICEEMAT) 10-12 December Proceeding Booklet.

[15] Roy, R., Fakhruddin, A. N. M., Khatun, R., Islam, M. S., (2010). Reduction of COD and $\mathrm{pH}$ of Textile Industrial Effluents by Aquatic Macrophytes and Algae. Journal of Bangladesh Academy of Sciences, 34(1), 9-14

[16] Singh, M. M., Rai, P. K. (2016). A microcosm investigation of $\mathrm{Fe}$ (iron) removal using macrophytes of ramsar lake: A phytoremediation approach. International Journal of Phytoremediation, 18(12), 1231-1236, D.O. 10.1080/15226514.2016.1193471
[17] Singh, P, Thakur, I. S. (2004). Removal of colour and detoxification of pulp and paper mill effluent by microorganisms in two step bioreactor. J. Scient. Ind. Res, 63(11), 944-948.

[18] Wolverton, B. C., McDonald, R. C. (1980). Comparative Study of Wastewater Lagoon with and without Water Hyacinth. Economic Botany, 34(2), 101-110.

[19] Yadav, S. B, Jadhav, A. S., Chonde, S. G., Raut, P. D. (2011). Performance evaluation of surface flow constructed wetland system by using Eicchornia crassipes for wastewater treatment in an institutional complex. Universal Journal of Environmental Research and Technology, 1(4), 435-441. 